\title{
Metody badawcze stosowane w pracach dotyczących ograniczania występowania populacji Globodera rostochiensis w glebie
}

\author{
Research methods used in experimental works of reducing Globodera rostochiensis \\ occurence in the soil
}

\section{Katarzyna Franke ${ }^{凶}$, Grzegorz Gryń, Lidia Michałowska, Mateusz Nowakowski}

Instytut Hodowli i Aklimatyzacji Roślin — Państwowy Instytut Badawczy

Oddział w Bydgoszczy, Al. Powstańców Wlkp. 10, 85-090 Bydgoszcz

凶e-mail: k.franke@ihar.bydgoszcz.pl

\begin{abstract}
Mątwik ziemniaczany i mątwik agresywny to dwa nicienie tworzące cysty na korzeniach ziemniaka. Zarówno w Polsce jak i w wielu innych państwach posiadają status organizmów kwarantannowych. Obecność mątwika ziemniaczanego może powodować straty w plonie bulw sięgające $50-80 \%$. Metody zwalczania mątwika można podzielić na trzy grupy: agrotechniczną, biologiczną i chemiczną. Pozyskane wyniki będą stanowiły podstawę opracowania zaleceń dla rolników, które usprawnią eliminację szkodnika.
\end{abstract}

Słowa kluczowe: Globodera rostochiensis, mątwik ziemniaczany, organizm kwarantannowy, zwalczanie, metodyka

Potato cyst and aggressive cyst are two nematodes forming cysts on the roots of the potato. In Poland and in many other countries they have the status of quarantine organisms. The presence of potato cyst nematodes may cause losses in the tuber yield reaching $50-80 \%$. Methods of fighting cyst nematode can be divided into three groups: agrotechnical, biological and chemical. The obtained results will be the basis for the development of recommendations for farmers, which will improve the elimination of the pest.

Key words: Globodera rostochiensis, potato cyst nematode, quarantine pest, disease control, methodology

Mątwik ziemniaczany Globodera rostochiensis i mątwik agresywny Globodera pallida (Stone, 1973) to dwa nicienie tworzące cysty na korzeniach ziemniaka. Należą do rodziny mątwikowatych (Heteroderidae). Zarówno w Polsce jak i w wielu innych państwach posiadają status organizmów kwarantannowych - podlegają szczególnemu nadzorowi fitosanitarnemu i obowiązkowi zwalczania z urzędu (Dz.U. Poz 1288 z 2016 r., Dz. U. z 2017 r., poz. 2138, z późn. zm.). Regulacje prawne dotyczą sposobów postępowania w przypadku wykrycia oraz metod zapobiegania rozprzestrzenianiu się nicieni.

Obecność mątwika ziemniaczanego może powodować straty w plonie bulw sięgające $50 \%$ (Seenivasan, 2017), a zdaniem niektórych badaczy nawet do 80\% (Zawiślak i in., 1989; Turner, 1996). Wykrycie nicienia skutkuje wprowadzeniem zaleceń kwarantanny $\mathrm{w}$ miejscach produkcji ziemniaków. Prowadzi to do wstrzymania produkcji nasiennej, utrudnia obrót sadzeniakami i eksport bulw. Mątwik należy do endopasożytów osiadłych. $\mathrm{Na}$ polu występuje miejscowo, co utrudnia wykrycie szkodnika podczas rutynowych kontroli prowadzonych przez PIORiN. Larwy i jaja nicienia przed czyn- nikami środowiskowymi, chemicznymi i uszkodzeniem mechanicznym chroni otoczka chitynowa (cysta). Cysty mogą przetrwać w glebie przez kilka lat, zapewniając inwazyjność larwom. Potencjalne źródło porażenia dla nowych miejsc stanowią cysty zawleczone $\mathrm{z}$ glebą z porażonego pola osiadłą na bulwach, narzędziach i sprzęcie rolniczym. Zwalczanie wykrytego na polu nicienia to poważny problem, który wymaga kompleksowego podejścia i racjonalnego połączenia wszystkich dostępnych metod.

W Polsce powszechnie występuje Globodera rostochiensis patotyp $\mathrm{Ro}_{1} \mathrm{i}$ sporadycznie $\mathrm{Ro}_{5}$ (Przetakiewicz, 2013). W przypadku wykrycia go $\mathrm{w}$ miejscu produkcji ziemniaka wymagane jest stosowanie kwarantanny w wyznaczanej strefie porażenia i strefie bezpieczeństwa. Obostrzenia dotyczą między innymi zakazu uprawy wybranych gatunków roślin, gospodarki odpadami, transportu oraz agrotechniki. Oceny obecności cyst można dokonać przez analizę prób gleby, jak również przez obserwację systemu korzeniowego ziemniaka w okresie kwitnienia.

Podstawową czynnością zapobiegającą rozprzestrzenianiu się szkodnika jest sadzenie 
ziemniaka na wolnym od nicieni polu. Aby uniemożliwić wprowadzenie mątwika ziemniaczanego na pole należy stosować wyłącznie zdrowy materiał sadzeniakowy; ważne jest także dokładne czyszczenie narzędzi i sprzętu rolniczego, na którym mogą wraz $\mathrm{z}$ resztkami ziemi znajdować się cysty. Wśród skutecznych metod ograniczania wielkości populacji nicienia, zaleca się również stosowanie podkiełkowanych sadzeniaków (do 90\% skuteczności) oraz roślin pułapkowych (Kornobis, 1982; Malec, 1985; Dandurand i Knudsen, 2016). Dopuszcza się również uprawę odmian odpornych ziemniaka. W polskim Krajowym Rejestrze na koniec 2018 r. znajdowało się zaledwie $6 \%$ odmian ziemniaka podatnych na porażenie przez Globodera rostochiensis patotyp $\mathrm{Ro}_{1}$. Należy mieć jednak na uwadze, że jedynie $25 \%$ odmian przebadano na wszystkich patotypach Globodera rostochiensis (www.coboru.pl).

Jako element integrowanej ochrony ziemniaka przed mątwikiem na uwagę zasługuje uprawa $\mathrm{w}$ płodozmianie roślin nieżywicielskich dla szkodnika. Pozwala ona na ograniczenie wielkości populacji nicienia do 50\%. Duże znaczenie mogą mieć uprawy międzyplonów ścierniskowych (Pastuszewska i in., 2013; Nowakowski i Franke, 2013) oraz wprowadzenie do płodozmianu upraw innych gatunków roślin( $\mathrm{w}$ tym $\mathrm{z}$ rodziny kapustowatych), które przyczynią się do redukcji populacji szkodnika $\mathrm{w}$ glebie (Ngala i in., 2014, Zambouri i Fatemy 2014; Fatemy i Sepideh, 2016).

Metody zwalczania mątwika można podzielić na trzy grupy: agrotechniczną, biologiczną i chemiczną. Dla poprawnej agrotechniki istotny jest przemyślany dobór gatunków roślin uprawnych włączonych do płodozmianu. Mątwiki żerują jedynie na roślinach $\mathrm{z}$ rodziny psiankowatych, dlatego wyeliminowanie ich z płodozmianu powoduje naturalne ograniczanie wielkości populacji nicienia $w$ glebie. Inne ważne zalecenie to maksymalnie wydłużony cykl zmianowania i stosowanie bardzo wczesnych odmian ziemniaka, o krótkim okresie wegetacji. Kontrolowanie cyklu rozwojowego nicieni pozwala na usunięcie z pola roślin ziemniaka zanim na korzeniach wykształcą się dojrzałe cysty.

Metoda chemiczna wykorzystuje dostępne na rynku środki ochrony roślin. Wyróżnia się wśród nich nematocydy selektywne (Vydate $10 \mathrm{G}$ ) oraz nieselektywne w postaci fumigantów glebowych, których aktualna lista dostępna jest na stronie Ministerstwa Rolnictwa i Rozwoju Wsi, w zakładce Rejestr Środków Ochrony Roślin.
Metoda biologiczna bazuje na antagonistycznych oddziaływaniach grzybów i bakterii występujących w glebie na larwy nicienia. W literaturze dostępne są wyniki badań nad nicieniobójczym działaniem grzybów z rodzaju Pochomia (Tobin i in., 2008) i Trichoderma (Contina i in., 2017).

Badania laboratoryjne i polowe dotyczące oceny wpływu różnych roślin na wyląg larw inwazyjnych mątwika ziemniaczanego (Globodera rostochiensis) patotyp $\mathrm{Ro}_{1}$ prowadzono $\mathrm{w}$ bydgoskim Oddziale IHAR PIB w Pracowni Chorób i Szkodników Kwarantannowych Ziemniaka .

W płytkach titracyjnych oceniano wpływ przesączy glebowych zawierających wydzieliny korzeniowe badanych roślin na larwy w cystach mątwika ziemniaczanego wybranego patotypu (Twomey i in., 1995). Ekstrakty roślinne ze względu na mniejszą trwałość testowano w komorach hodowlanych umożliwiających okresową wymianę ekstraktu na świeży. Cysty wykorzystywane do badań rozmnażano na podatnej odmianie ziemniaka $\mathrm{w}$ warunkach kontrolowanych.

Badania przesączy glebowych prowadzono na reprezentatywnej grupie cyst dla danej populacji i patotypu nicienia. W 96-dołkowych płytkach titracyjnych umieszczano badany odciek i po jednej cyście w każdym dołku (wcześniej moczonej przez $24 \mathrm{~h}$ w wodzie). Oceny wylęgu larw dokonuje się kilkukrotnie w odstępach czasowych (co 7 dni). Następnie badany odciek wymieniano na kontrolny, pozyskany $\mathrm{z}$ uprawy pomidora (odmiana Moneymaker), w celu zweryfikowania liczby żywych larw pozostałych w badanych cystach. Ocena dokonywano w przyjętej na potrzeby badań 5-stopniowej skali, która określa liczbowo nasilenie wylęgu larw z cyst.

Ekstrakty pozyskiwano $\mathrm{z}$ suszonych oraz świeżych części roślin: części nadziemnej, korzeni, nasion, siewek, a także odpadów poprodukcyjnych. Z materiału przeznaczonego do badania przygotowywano wodne ekstrakty (Aires, 2009). Cysty w woreczkach nylonowych, umieszczano w komorach hodowlanych $\mathrm{z}$ dodatkiem odpowiednio rozcieńczonego ekstraktu. Co kilka dni określano liczbę larw, które wydostały się z cysty przy pomocy mikroskopu odwróconego, a woreczki z cystami przekładano do nowych komór hodowlanych zawierających świeże ekstrakty. Po okresie, w którym następuje największy, masowy wyląg larw, cysty z woreczków są wyjmowane, umieszczane pojedynczo 
w „dołkach” płytki titracyjnej i zalewane odciekiem $\mathrm{z}$ pomidora $\mathrm{w}$ celu oszacowania liczby żywych osobników pozostałych w cystach.

Doświadczenia wazonowe prowadzono w okresie: czerwiec - wrzesień na polu doświadczalnym. Pozwalają one na bardzo precyzyjną ocenę zmiany wielkości populacji nicieni, jaka zachodzi podczas uprawy testowanych roślin. Przyjęta liczba cyst z oszacowaną wielkością populacji larw w specjalnych nośnikach w postaci woreczków nylonowych umieszczano $\mathrm{w}$ kilku miejscach $\mathrm{w}$ wazonach z podłożem glebowym. Badane rośliny wysiewano w kombinacjach bez dodatku i z dodatkiem czynnika stymulującego wyląg larw (rozdrobnione korzenie ziemniaka odmiana Miłek). Obiekty kontrolne stanowią wazony bez obsiewu oraz z roślinami ziemniaka odmiany podatnej i odpornej. Ocenie poddano końcową wielkość populacji nicienia w cystach umieszczonych w woreczkach nylonowych. Sprawdzona została również potencjalna obecność nowo wytworzonych cyst w próbach gleby.

Do doświadczeń polowych wyznaczono poletko doświadczalne, spełniające warunki wymagane do badań z organizmami kwarantannowymi, sztucznie zasiedlane populacją nicieni i podtrzymywaną przez wysadzanie odmian ziemniaków podatnych na porażenie przez mątwika ziemniaczanego. Badania dotyczyły oceny wpływu uprawy różnych roślin nieżywicielskich na wyląg larw $\mathrm{z}$ cyst. Doświadczenia trzyletnie, założono metodą losowanych bloków, w czterech powtórzeniach. Oceny liczebności populacji mątwika dokonywano dwukrotnie: $w$ dniu wysiewu oraz po zbiorze roślin. Próby gleby pobierano z głębokości 0-20 cm laską Egnera i starannie mieszano. Wielkość populacji oceniano w $100 \mathrm{ml}$ wysuszonej powietrznie gleby. Próby przesiewano przez zestaw sit, w celu odrzucenia części organicznej i zanieczyszczeń. Cysty wypłukano z prób gleby przy pomocy uproszczonej metody butelkowej poddano pojedynczo ocenie zawartości żywych larw przy użyciu mikroskopu stereoskopowego.

Dodatkowym czynnikiem badanym w doświadczeniach polowych była ocena biomasy uprawianych roślin. W każdym roku badań $\mathrm{w}$ okresie wegetacji prowadzono pomiary dynamiki wzrostu roślin i intensywności kwitnienia. Po zbiorze określano wielkość plonów części nadziemnej i korzeni. Pobierano próby materiału roślinnego do oceny zawartości suchej masy i wartości nawozowych. Wszystkie uzyskane wyniki poddano analizie statystycznej. Prace laboratoryjne służą jako narzędzie badawcze, niezbędne do opracowania skutecznych metod zwalczania mątwika ziemniaczanego. Pełnią funkcję poznawczą i pozwalają na wstępną, szybką laboratoryjną ocenę wpływu różnych czynników biologicznych na śmiertelność nicieni. Badania polowe umożliwiają weryfikację wyników badań uzyskanych w warunkach laboratoryjnych. Pozyskane wyniki będą stanowiły podstawę opracowania zaleceń dla rolników, które usprawnią eliminację szkodnika w momencie wykrycia go przez PIORiN.

\section{Literatura}

Aires A., Carvalho R., Da Conceição Barbosa M., Rosa E. 2009. Suppressing Potato Cyst Nematode, Globodera rostochiensis, with Extracts of Brassicacea. Plants. Am. J. Pot Res., 86: 327 - 333 .

Contina J. B., Dandurand L. M., Knudsen G. R. 2017. Use of GFP-tagged Trichoderma harzianum as a tool to study the biological control of the potato cyst nematode Globodera pallida. Applied Soil Ecology 115: 31 37.

Dandurand L. M., Knudsen G. R. 2016. Effect of the trap crop Solanum sisymbriifolium and two biocontrol fungi on reproduction of the potato cyst nematode, Globodera pallida Annals of Applied Biology 169: $180-189$.

Fatemy S., Sepideh A. 2016. Adverse effects of brassica green manures on encysted eggs, infective second-stage juveniles and the reproduction of Globodera rostochiensis. J Plant Dis Prot., 123: $225-233$.

Kornobis S. 1982. Problemy i metody zwalczania mątwika ziemniaczanego - Mater. XXII i XXIII Sesji Nauk. IOR., IOR Poznań: $69-76$.

Malec K. 1985. Mątwik Ziemniaczany (Globoderas rostochiensis Woll.) i Mątwik Agresywny (Globodera pallida Stone). Wyd. IZ Bonin: 32 ss.

Ngala M. B., Haydock P. P. J., Woods S., Back M. A. 2014. Biofumigation with Brassica juncea, Raphanus sativus and Eruca sativa for the management of field populations of the potato cyst nematode Globodera pallida. Pest Manag. Sci. 2015; 71: $759-769$.

Nowakowski M., Franke K. 2013. Struktura plonu i oddziaływanie na populację mątwika ziemniaczanego (Globodera rostochiensis) wybranych odmian gorczycy białej uprawianej w plonie głównym II. Plony biomasy nadziemnej i korzeni oraz zagęszczenie mątwika ziemniaczanego w glebie. Rośliny Oleiste Oilseed Crops: 34 (1): 85 - 94.

Pastuszewska T., Franke K., Nowakowski M. 2013. Badanie wpływu uprawy gorczycy białej na zagęszczenie populacji mątwika ziemniaczanego (Globodera rostochiensis) w glebie. Biul. IHAR 269: $141-148$.

Przetakiewicz A. 2013. The first report of Globodera rostochiensis pathotypes Ro5 occurrence in Poland. Disease Notes, 97/8: 1125.

Seenivasan N. 2017. Status of potato cyst nematodes, Globodera spp. infection on potato at Kadaikanal hills 
of Tamil Nadu, India and yield loss estimation. Journal of Entomology and Zoology Studies: 5 (5): $268-272$.

Tobin J. D., Haydock P. P. J., Hare M. C., Woods S. R., Crump D. H. 2008. Effect of the fungus Pochonia chlamydosporia and fosthiazate on the multiplication rate of potato cyst nematodes (Globodera pallida and G. rostochiensis ) in potato crops grown under UK field conditions. Biological Control 46: $194-201$.

Turner S. (1996). Population decline of potato cyst nematodes (Globodera rostochiensis, G pallida) in field soils in Northern Ireland. Ann. Appl. Biol. 129: 315 322.
Twomey U., Raftery T., Devine K., Jones P. W. 1995. An improved procedure for assaying hatching activity of potato root diffusate towards Globodera rostochiensis. Nematologica 41: 258 - 260.

Zanbouri B. P., Fatemy S. 2014. Two methods of evaluating bionematicide effects of Mentha pulegium and Lepidium sativum on hatching of Globodera rostochiensis. Aspects of Appled Biology: 133 - 137.

Zawiślak K., Tyburski J., Rychcik B. 1989. Sigficance of crop rotation and cultivars resistantr to potato cyst nematode on potato production. Effects of crop rotations on potato production in the temperate zones: $111-119$.

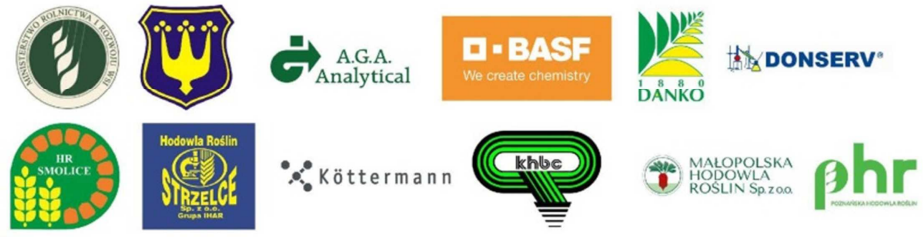

